\title{
Interrelation of spatial disparities in development and migration patterns in transition economy: Serbia - Case study
}

\author{
Vesna Lukić*, Marija Anđelković Stoilković
}

Institute of Social Sciences, Serbia

The post-socialist transition processes in Serbia stepped up the existing disparities in development between the regions as well as between the municipalities. In the attempt to contribute to the EU and national knowledge on this topic, this paper focuses on interrelation between migration and development inequalities in Serbia in terms of negative natural increase, traditional emigration and small scale immigration, which challenge the balanced distribution of Serbian population and affect social change. The objective of the paper is to explore the interaction between migration and inequalities in transition economy of Serbia and to identify the underlying determinants. The indicators used in the regression analysis are the net migration rate for the inter-census period 2002-2011 and the set of demographic, socio-economic and geographic quantitative indicators. The findings reveal the interaction of migration and level of development in Serbia suggesting the importance of geographic location besides the socio-economic factors .

Key Words: migration, disparities, border municipalities, regression analysis, Serbia.

Article Info: Received: February 20, 2017; Revised: April 20, 2017; Accepted: May 10, 2017; Online: May 25, 2017.

\section{Introduction}

The socio-economic disparities as a subject are actual and significant from various social aspects. Many researches pursue this question in the light of determinants and the outcomes of spatial disparities in economic activity, incomes and social indicators as the basis for various development policies of concern for the national and EU policy makers (Puga, 1999; Martin, 2005;

\section{* Corresponding author}

Address: Institute of Social Sciences - Demographic Research Center, Kraljice Natalije 45, 11000, Belgrade, Serbia.

Phone: +38111361389| Email: lukicbodirogav@gmail.com

(C)2017 Human Geographies; The authors

(c) (i) This work is licensed under a

Creative Commons Attribution 4.0 International License. DOI:10.5719/hgeo.2017.111.4 
Nazarczuk, 2015; Enflo, Ramon Roses, 2015). Reducing regional disparities has been one of the main goals of the European Union (EU), which has devoted an increasing share of its budget to regional policy (Bouvet, 2008:2). Yet, the socioeconomic inequality in Europe is rising. High level of regional disparities is specially expressed in transition countries which conduct deeper economic changes (Dillinger, 2007; Kallioras, 2010; Michálek, Podolák, 2011). Research on inequalities in labor market, social security, education and workplace health gaps has shown that, observed on the EU level, the 'weakest' European NUTS-2 regions, as measured by GDP per capita as a percentage of the EU average, are in states that joined the post-2004 wave of expansion (ETUI, 2012:94).

Debate over connections between migration and development or "migrationdevelopment nexus" historically was framed through different phases: the optimism, the pessimism and the win-win phase (de Haas, 2010). When discussing spatial disparities in development, the issues of population and migration (regional inequality-migration nexus) receive scholars' attention regarding national or comparative research (Kallioras, 2010; Borozan, 2015; Portnov, 1999). According to "pessimistic" cumulative causation theory (Massey, 1990), migration is strongly related to economic and social inequality affecting scope and structure of population in the areas of origin and destination and engendering further disparities without tackling this issue. The experience of EU countries confirms that even nowadays, despite economic progress, low income and high level of unemployment in certain regions represent significant push factor for migration and deepen regional differences (Bélorgey et al. 2012; Borozan, 2015). In different societies research on the link between migration and inequality through a set of structural determinants has shown that unemployment and income level in a certain extent affect migration, but that other factors such as spatial characteristics and housing opportunities are important as well (Michálek, Podolák, 2011; Gezici, Keskin, 2005; Portnov, 1999).

Previous research focusing on spatial inequalities in Serbia (Grcic, Ratkaj, 2006; Tosic et al. 2009; Miljanovic et al. 2010) did not include migration component. Solely research on the development disparities and migration in Serbia referred to regional dimension of deindustrialization and commuting in selected industrial centers. The results of the research pointed out that adjustment to changes in the labor market have been through outmigration rather than commuting (Miletic et al. 2011). Therefore, this paper can bring added value to the research on spatial disparities in the levels of socio-economic development of transition societies highlighting the inter-relation between migration and development inequalities as well as identifying migration determinants in Serbia. The aim of the paper is to explore and understand, through regression analysis, how spatial disparities in development influence the migration patterns in Serbia.

\section{Spatial Inequalities and Migration Trends in Serbia}

Inter-regional and intra-regional disparities observed in the European countries are also one of the most pressing challenges in the Republic of Serbia. With $35 \%$ of the EU average (according to BDP per inhabitant by purchasing power) and the most developed Belgrade region (60\%) and the most undeveloped region of 
Southern and Eastern Serbia (22\%), Serbia is among those European countries with the largest regional differences (Government of the Republic of Serbia GORS, 2014). According to the First National Report on Social Inclusion and Poverty Reduction of Serbian Government, the ratio between the most developed and the most underdeveloped municipality, observed according to level of economic development, was 10:1 in 2008 (GORS, 2011:70). Research of the structure of the development inequality in Serbia for the period 2001-2010, points out that the largest contribution to total inequality until 2006 was given by the part of inequality that exists between municipalities, which, at later stages, was gradually leveled with contribution of interregional component (Molnar, 2013).

Besides North-South and urban-rural differences in the development as opposite to large urban centers, there are municipalities in Serbia that have had the status of underdeveloped for decades (Tosic et al. 2009). According to the Spatial Plan of the Republic of Serbia from 2010 to 2020, based on demographic, social and economic indicators, out of 161 municipalities, 41 of them have been characterized as underdeveloped, whereas 19 of them were characterized as devastated. Devastated area encompasses industrial cities which have lost more than $40 \%$ of their business income and more than $50 \%$ of employees from processing industry in the period 1990-2008 (The Law on Spatial Plan of the Republic of Serbia from 2010 to 2020, hereinafter referred to as the SPRS).

The process of Serbia's economy and society transformation since 2000 has emphasized the regional inequalities which are bespoken in large economic differences, especially when it comes to level of unemployment growth, effects of privatization and scope of foreign investments (Jakopin, Devetakovic, 2009). Pronounced differences at the level of regions as well as the level of municipalities in labor market outcomes such as unemployment rates and wages but also in industry structure are also huge at the level of development of road and telecommunication infrastructure, availability and quality of health care and other domains.

In the last decade of the 20th century the restructuring of the industry sector, which had a dominant position in centrally planned economies, had negative effect upon mono-industrial areas in Serbia similar to other postsocialist countries (Redei, 2010; Michalek, Podolak, 2011). This led to growth of spatial disparities in development and lagging behind structurally disadvantaged cities/regions with inherited economic specialization, which became the losers of transition (Miljanovic et al. 2010). Structural changes and transition to market economy and regional implications of deindustrialization deepen the spatial socio-economic gap, which influences the scope and direction of migration flows in Serbia. Regional and municipality dimensions of population change are the outcome of the long-lasted polarization of population and investments at larger municipal and regional centers of the Danube-Morava corridor, while the rural and peripheral areas are affected by long-term emigration. Internal migration flows have had the same direction for decades following the patterns of socio-economic development and intensifying North-South and urban-rural disparities (Lukic, 2013). Large number of municipalities in Serbia had negative net migration rate between 2002 and 2011, while the majority of Belgrade municipalities and other larger macro-regional centers which offer 
greater choice of jobs and higher income had positive migration rate in this period. Certain underdeveloped municipalities have extremely low negative values of migration rate (Medveda $-31.1 \%$, Majdanpek $-17.8 \%$, Crna Trava $16.7 \%$, Trgovište $-15.3 \%$ ), whereas the Belgrade city municipalities have the highest values of migration rate (Barajevo 15.6\%, Zvezdara 15.2\%o, Surčin $13.9 \%$ ) (Figure 1).

The depopulation along with intense emigration characterizes a large number of post-socialist countries. Serbia is the country with long tradition of emigration and small scale immigration. The first large emigration wave was in the late 1960s and early 1970s, mostly induced by socio-economic reasons and the second one in the 1990s characterized by adversely political, social and economic developments in Serbia and war in the territory of former Yugoslavia.

The crisis in Serbia during the last decade of the 20th century, on the account of the political and economic disintegration of the SFRY (Socialist Federal Republic of Yugoslavia), the UN Security Council sanctions and the NATO bombing, had its demographic and socio-economic consequences. The political crisis and a sense of lost perspective for a large part of the population, and especially for the young generation, were the main push factors of intense emigration from the country in the 1990s. In the inter-census period 1991-2002 an increase of over $50 \%$ of Serbian citizens working or staying abroad was recorded (Lukic et al. 2013).

The trend of negative natural increase of population in Serbia recorded since 1992 , contributed to the increase of the significance of migration component of population change. Negative demographic trend as an outcome of emigration and negative natural increase of population was partly compensated by influx of refugees from the former Yugoslav republics, Bosnia and Herzegovina and Croatia. Namely, during the war on the territory of former Yugoslavia, Serbia received a large number of refugees from the former republics, mostly the coethnic population from Bosnia and Herzegovina and Croatia. The share of those from other former Yugoslav republics, Slovenia and Macedonia, is significantly lower and they jointly accounted for less than $1 \%$ of the total observed population in 2002.

The largest number of refugees settled in Vojvodina, due to migrant networks effect. Other than on the population change, the refugees have not had a more significant impact on the changes of the natural increase of the population or on its socio-economic characteristics in the regions where they have settled. The demographic effects of refugee migration are more evident only in the municipalities of Indjija, Ruma, Sremski Karlovci, Stara Pazova and Sid where refugees make one quarter of the total population in 2002 (Lukic, Matijevic, 2006). Although the mobility of refugees was not high in the first years of refugeeism, due to strong influence of social networks, the data show that over time, they became more mobile. By moving over larger distances in comparison with the local population, their destinations are most often the urban settlements in the Belgrade region and the Region of Vojvodina.

According to the 2011 census data, within the total number of unemployed long term settled refugees from former Yugoslavia, two thirds accounted for persons who used to work once and one third for those who were looking for their first job. They had major difficulties in integration on the labour market, 


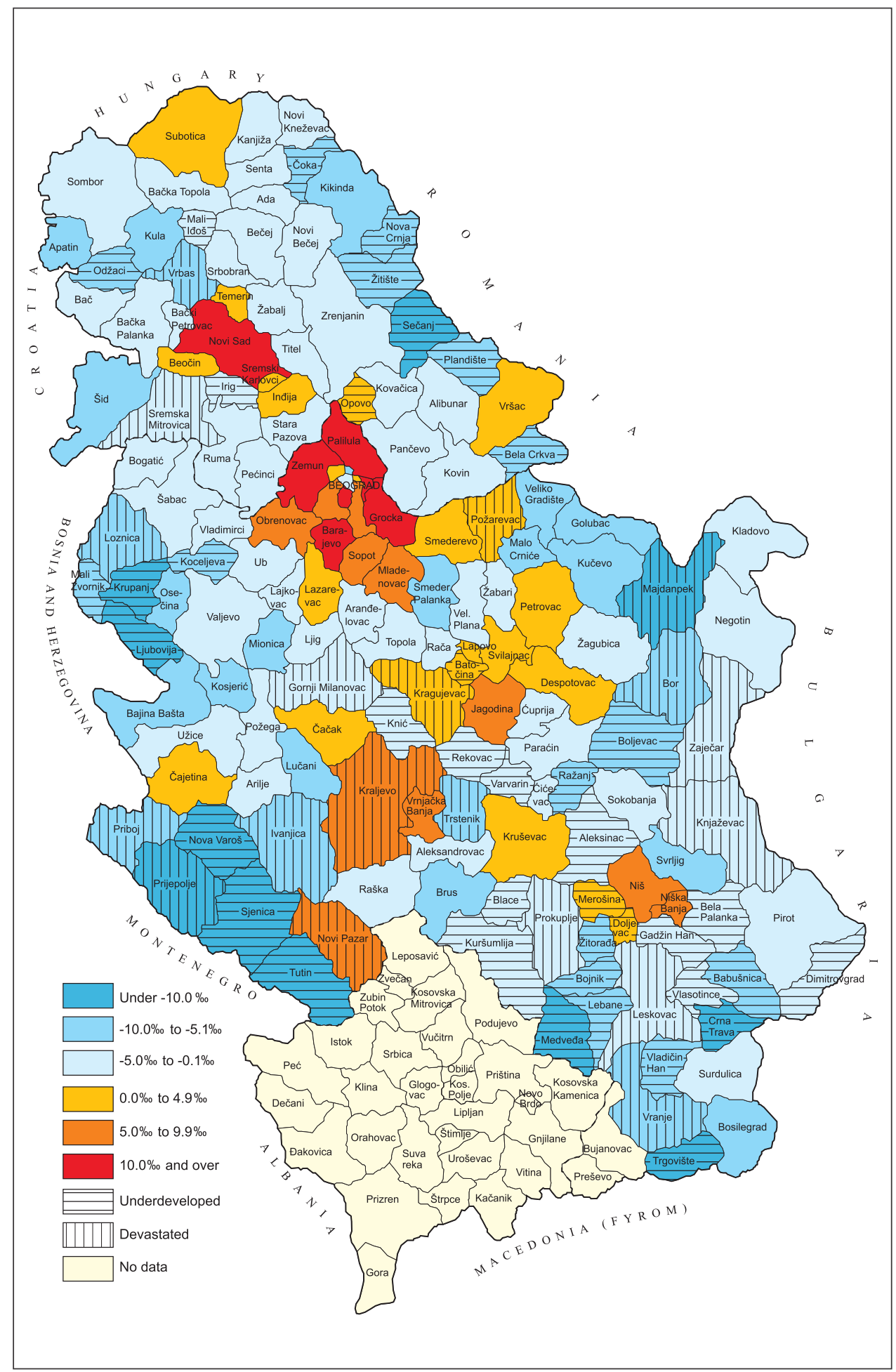

Figure 1. The average annual migration rate by municipalities in Serbia in the period 2002-2011 
especially due to economic slowdown in the 90s and high unemployment of the host-country population. This influenced their positive approach to entrepreneurial activities. The 2011 census data indicated a slightly higher share of the long term settled refugee entrepreneurs (8.2\%) in the economically active population compared to the host population (6.7\%) (Lukic, 2016). Continuation of the decline of Serbia's t population could not be offset by refugee influx due to too small number of refugees comparing to the total population size of Serbia; similarity in fertility behavior between refugee and indigenous population and much older refugee population compared to emigrant population (Nikitovic, Lukic, 2010).

Rough estimate of the current net migration balance of the country is between $-10,000$ and $-15,000$ persons per year (Lukic et al. 2013). Nevertheless, not all regions in Serbia are equally affected by emigration. Significant regional differences in terms of emigration trends date back from the mid-1960s, and they gradually developed and further intensified afterwards, both at the lower (cities and municipalities) and the higher territorial levels (districts and regions). These differences are even more pronounced at lower territorial and administrative levels where the diversity of demographic and economic development can be clearly seen (Predojevic-Despic, Penev, 2014).

Long history of emigration exhausted most of the demographic potential of rural areas in Serbia, ergo regional dimension of demographic change is seen in the increase in number of settlements without inhabitants and those with the population under 100 inhabitants. Due to the selectivity of migrants by age, the emigration contributed to the accelerated ageing of the rural and peripheral areas which also had impact on population growth. These are mainly mountainous or border villages of underdeveloped municipalities in East and Southeast Serbia and in the contact zone with AP Kosovo and Metohija (Lukic, 2013). Previous research on the underdeveloped areas in Serbia shows that they are facing economic, demographic and social problems with population that decreases ten times more on average per year than that of the Republic of Serbia (Tosic, et al. 2009). These trends referred to the low economic activity of underdeveloped area and the high unemployment rate, which were two times higher than the national average in the 2008 financial crisis year. Consequently, low employment rate and economic activity generate the increase in the number of poor population living in underdeveloped areas (GORS, 2011). The unemployment rate in Serbia amounted to $21.9 \%$ in 2011 and $25.4 \%$ for underdeveloped municipalities respectively (SORS, 2013).

Due to the constant population decline within the underdeveloped areas and the unfavorable age structure, as well as educational structure of ageing labor force which, by its performance, cannot meet the demands of the labor market, the human factor is becoming a big constraint to development (Lukic, 2013; Jokic et al. 2015).

\section{Data and Methodology}

According to official regional division based on the EUROSTAT criteria, which incurred from the need to harmonize statistical territorial units with the EU, 
Table 1. Dependent and independent variables for regression analysis

Dependent variable

\begin{tabular}{|c|c|c|}
\hline Var 1 & & Net migration rate, $2002-2011$ \\
\hline \multicolumn{3}{|c|}{ Independent variables } \\
\hline \multirow{2}{*}{$\begin{array}{l}\text { Demographic } \\
\text { variables }\end{array}$} & Var 2 & Total population, 2011 \\
\hline & Var 3 & Natural increase rate, $2002-2011$ \\
\hline \multirow{5}{*}{$\begin{array}{l}\text { Socio-economic } \\
\text { variables }\end{array}$} & Var 4 & Unemployment rate, average 2002-2011 \\
\hline & Var 5 & Per capita income, average 2002-2011 \\
\hline & Var 6 & Public investments, average 2002-2011 \\
\hline & Var 7 & $\begin{array}{l}\text { Number of inhabitants per doctor, average 2002- } \\
2011\end{array}$ \\
\hline & Var 8 & Labor force with at least secondary education, 2011 \\
\hline \multirow{3}{*}{ Geographic variables } & Var 9 & Region to which municipality belongs \\
\hline & Var 10 & Central/border location of municipality \\
\hline & Var 11 & $\begin{array}{l}\text { Old/new border municipality, only for border } \\
\text { municipalities. }\end{array}$ \\
\hline
\end{tabular}

Serbia is divided into five NUTS2 relatively homogenous regions: Belgrade; Vojvodina; Šumadija and West Serbia; South and East Serbia; Kosovo and Metohija. However, municipalities within the regions are heterogeneous. Besides North-South differences in development, border municipalities are peripheral in relation to development centers and infrastructural corridors, they are underdeveloped in relation to the average of the Republic of Serbia and deteriorated in socio-economic and population way.

Border regions are also marginalized and structurally disadvantaged in other post-socialist countries that have changed borders and economic systems (Williams et al., 2001). Out of 46 border municipalities, 16 of them have been characterized as underdeveloped and 7 as devastated (SPRS, 2010). The process of industrialization based on the centralized politics, which was conducted during the second half of the 20th century has had the influence on the increase of the border area "isolation". Economic centers have been settled in the inlands, mainly due to strategic and safety reasons. Due to the diversity of international borders in Serbia, the "new" border municipalities (19) that were formed on the border with the former Yugoslav republics after the war in the 1990s had better development positions and chances than those border municipalities with "long tradition" (Figure 1).

Multiple regression analysis as effective method for migration research was used to depict the most important factors influencing migration in Serbia. Standard multiple regression analysis was made in the SPSS program. Net migration rate (Var 1) in the inter-census period 2002-2011 represents dependent variable, while the independent variables have been divided into three groups aiming to measure the effect of development inequalities on migration (Table 1).

The variables are selected according to the relevant literature and also the OECD regional well-being indicators (OECD, 2016), considering available data from various national sources (SORS - Statistical office of the Republic of Serbia and GORS - Government of the Republic of Serbia strategic documents). All variables are numeric, except the geographic ones. The variables 10 and 11 
Table 2. Regression analysis of background variables and migration in municipalities of the Republic of Serbia

\begin{tabular}{|c|c|c|c|c|c|c|c|c|c|}
\hline \multirow{3}{*}{ Variables } & \multicolumn{5}{|c|}{ Values of Regression Analysis } & \multicolumn{4}{|c|}{$\begin{array}{l}\text { Importance of variables } \\
\text { for regression analysis }\end{array}$} \\
\hline & \multirow{2}{*}{$r$} & \multirow{2}{*}{$r^{2}$} & \multirow{2}{*}{$\begin{array}{l}1- \\
r^{2}\end{array}$} & \multicolumn{2}{|c|}{ Anova } & \multirow{2}{*}{$\begin{array}{c}\text { Model } \\
\text { Constant }\end{array}$} & \multirow{2}{*}{$\begin{array}{l}\text { One } \\
\text { Sample } \\
\text { T Test } \\
-\end{array}$} & \multirow{2}{*}{$\begin{array}{l}\text { Unstandardized } \\
\text { Coefficients B } \\
-9.536\end{array}$} & \multirow{2}{*}{$\begin{array}{l}\text { Sig. } \\
.248\end{array}$} \\
\hline & & & & $F$ & Sig. & & & & \\
\hline \multicolumn{6}{|c|}{ All municipalities } & Var 2 & .000 & $6.110 \mathrm{E}-005$ & .000 \\
\hline All & 0.720 & 0.518 & 0.482 & 17.803 & .000 & Var 3 & .000 & .081 & .408 \\
\hline Demographic & 0.531 & 0.282 & 0.718 & 30.660 & .000 & Var 4 & .000 & -.032 & .013 \\
\hline $\begin{array}{l}\text { Socio- } \\
\text { economic }\end{array}$ & 0.487 & 0.237 & 0.763 & 9.527 & .000 & Var 5 & .000 & .000 & .024 \\
\hline Geographic & 0.546 & 0.298 & 0.702 & 33.173 & .000 & Var 6 & .000 & 4.976E-008 & .785 \\
\hline \multicolumn{6}{|c|}{ Border municipalities } & Var 7 & .000 & -.002 & .160 \\
\hline All & 0.765 & 0.586 & 0.476 & 5.346 & .000 & Var 8 & .000 & -.120 & .236 \\
\hline Demographic & 0.523 & 0.273 & 0.238 & 7.709 & .001 & Var 9 & .000 & 2.606 & .000 \\
\hline $\begin{array}{l}\text { Socio- } \\
\text { economic }\end{array}$ & 0.718 & 0.515 & 0.452 & 8.080 & .000 & Var 10 & .000 & 4.744 & .000 \\
\hline Geographic & 0.257 & 0.066 & 0.020 & 1.445 & .248 & Var 11 & .000 & -1.570 & .246 \\
\hline
\end{tabular}

Source: Authors' calculation

were given the values of 0 or 1 depending on the fact whether the municipality is border one or not and whether it is old or new border municipality. Var 9 was given the value from 4 to 1 according to the North-South and East-West position of the region, with the Region of Belgrade with the highest value, then Vojvodina (2), Šumadija and West Serbia (3) and South and East Serbia (1).

\section{Results and Discussion}

The results of the test are made with the Pearson correlation method yielded $r=0.720$ (Table 2). As can be seen from the $r$ value, there is a high-level direct relationship. The coefficient of decision-making $\mathrm{r}^{2}=0.518$ shows that $51.8 \%$ of the variability of dependent variable can be explained by independent variables. The values in the column Anova show that independent variables statistically very well predict the dependent variable, namely that the regression model is a good one.

One of the goals of the analysis was to determine the mutual influence of demographic, socio-economic and geographic groups of variables on the migration rate. Regression analyses have been conducted for these groups of variables and the results point out that there is a positive relation of medium strength between dependent and independent variables. The influence of geographic variables is slightly higher in relation to demographic and socioeconomic ones. Anova values are also important with these models as well. In the model, One Sample T Test was applied to test the significance of coefficients. The values of the $\mathrm{T}$ test presented in the table point that all independent variables are significant for the analysis $(.000<0.05)$. 
Negative values of the Unstandardized Coefficients B indicate the opposite direction for the variables unemployment rate, the number of inhabitants per doctor, labor force with at least secondary education and old/new border municipality meaning that the emigration increases with the higher values of these variables. Other variables have positive values of this coefficient. The independent variable central/border location, which was used in regression model for all municipalities, was replaced by the variable old/new border municipality in the group of border municipalities.

Geographic variables Region to which municipality belongs and Central/border location of municipality are the most effective variables that determine the net migration rate. They are followed by a demographic variable Total population and the socio-economic variables Unemployment rate as the indicator of local labor market conditions and economic growth and Per capita income for its connection with living standard.

Region to which municipality belongs is a highly statistically significant variable in the analysis. The municipalities in the Belgrade region have the migration rate average value of $7.1 \%$, the municipalities in the Region of Vojvodina and the Region of Šumadija and West Serbia $-3 \%$ respectively, whereas the municipalities in the Region of South and East Serbia have $-5 \%$.

The Belgrade Region is more developed than the Vojvodina Region, i.e., it is much more developed than the region of Šumadija and West Serbia and the region of South and East Serbia. This is confirmed by analyzed socio-economic indicators: the number of unemployed per 1000 persons: 78; 130; 115 and 118 (average of Serbia, 113); index value of the level of salary compared to the average of Serbia (100\%): 116.4; $93.1 ; 79.9$ and 80.5 , by regions respectively; index value of the level of investment compared to the average of Serbia (100\%): $423.6 ; 118.1 ; 37.8$ and 44.4 , by regions respectively; number of inhabitants per 1 doctor: 580; 722; 758 and 608 (average of Serbia, 685).

Municipalities with larger number of inhabitants are more developed, which is why they attract population from underdeveloped municipalities. Therefore, the Belgrade city municipalities and the city municipalities of Novi Sad and Niš have the highest migration rate values (Figure1). Also, the municipalities with higher unemployment rates are those having the higher number of emigrants, because unemployment is, along with the income, one of the main push factors (municipalities with more than 150 of unemployed persons per 1000 inhabitants have $-5.3 \%$ of the migration rate, whereas the municipalities with fewer unemployed people have $-1.8 \%$ on the average).

One of the starting hypotheses was that the border municipalities are less developed and the population from these municipalities emigrates at larger scales. The results show that the variable central/border location has high statistical significance for the analysis. The migration rate in border municipalities equals $-6.2 \%$, whereas in other municipalities it is $-1.0 \%$. However, the type of the border municipality (old or new) variable has not proven itself to be of statistical significance. Unlike all municipalities in Serbia, the migration rate of border municipalities is particularly conditioned by socio-economic variables, and then demographic ones, while the impact of geographic variables is considerably smaller. 


\section{Conclusion}

Serbia is one of those European countries with the highest regional disparities. Emigration of young, working age population has caused numerous demographic, economic and social problems in the emigration areas over the years. While the rural, mountainous and border areas have been struck by emigration, immigration municipalities are bigger regional centers which attract population from underdeveloped areas and provide more opportunities for employment and higher salaries.

By using the demographic, socio-economic and geographic indicators, we have shown the specific role of the determinants in the inter-relation between migration and development while broadening the territorial focus of migrationdevelopment nexus in transition economies on the Republic of Serbia.

Findings of the regression analysis reveal the interaction of migration and socio-economic development in Serbia while suggesting the importance of geographic location. The influence of geographic variables is slightly higher in relation to demographic and socio-economic groups of variables. Statistically significant variables are region to which municipality belongs and central or peripheral location of municipality pointing to the North-South, as well as the center-periphery disparities. Thus one of the starting hypotheses has been confirmed that border municipalities are struck by long-term emigration, where the highest rates of emigration have been recorded. Other statistically important variables which have the influence on migration rate are number of inhabitants, then economic indicators unemployment and income size, which determine the living standard of population. These economic indicators have also proven themselves to be important in other transitional economies. The results of the research show that the importance of socio-economic factors in migration is even more pronounced in border municipalities. Border municipalities in Serbia take a lead in the number of unemployed persons, as well as in the low income, which seem as distinct push factors, which additionally abet emigration and deepen regional differences.

While addressing the challenges of the spatial disparities in socio-economic development deepened by the effects of post-socialist deindustrialization, Serbia can learn from international experience of other post-socialist transition countries, members of the EU. The Europeanization of spatial planning (Kunzmann, 2006) might be useful mechanism in resolving the spatial impacts of emigration and preserving human resources important for the planning.

\section{References}

Bélorgey, N, Garbe-Emden, B, Horstmann, S, Kuhn, A, Vogel, D \& Stubbs, P 2012, 'Social Impact of Emigration and Rural-Urban Migration in Central and Eastern Europe', European Union, Synthesis Report, GVG, Köln, VT/2010/001, viewed 1 August 2016, https://goo.gl/fraBMF.

Borozan, Dj 2015, 'Internal Migration, Regional Economic Convergence, and

Growth in Croatia', International Regional Science Review, pp. 1-23.

Bouvet, F 2008, 'Dynamics of regional income inequality in Europe and impact of 
EU regional policy and EMU', 4th DG ECFIN Annual Research Conference 'Growth and income distribution in an integrated Europe: Does EMU make a difference', Brussels, viewed 1 August 2016, https://goo.gl/uGpy0g.

De Haas, H 2010, 'Migration and development: a theoretical perspective', International Migration Review, vol. 44, no. 1, pp. 227-264.

Dillinger, W 2007, 'Poverty and Regional Development in Eastern Europe and Central Asia', World Bank Working Papers, no. 118, Washington.

European Trade Union (ETUI) 2012, Benchmarking working Europe 2012. Brussels ETUI, viewed 15 July 2016, https://goo.gl/9pbnJx.

Enflo, K \& Ramon Roses, J 2015, 'Coping with regional inequality in Sweden: structural change, migrations, and policy, 1860-2000', Economic History Review, vol. 68, no. 1, pp. 191-217.

Gezici, F \& Keskin, B 2005, 'Interaction between Regional Inequalities and Internal Migration in Turkey', ERSA Conference Papers, 1-18., viewed 15 July 2016, https://goo.gl/N5wkQL.

Grčić, M \& Ratkaj, I 2006, 'Structural Changes and Regional Differentiation of Industry in Serbia in the Period of Transition (1988-2005)', Glasnik Srpskog geografskog društva, vol. 86, no. 2, pp. 97-112.

GORS 2011, First National Report on Social Inclusion and Poverty Reduction in the Republic of Serbia, viewed 4 July 2016, https://goo.gl/hcv3dc.

GORS, 2014, Izveštaj o regionalnom razvoju Srbije 2013, viewed 4 July 2016, https://goo.gl/0jcYDg.

Jakopin, E \& Devetaković, S 2009, 'Regionalizacija u Srbiji', in B Cerović \& M Kovačević, (eds), Tranzicija u Srbiji i globalna ekonomska kriza, Ekonomski fakultet, Beograd, pp. 83-103, viewed 2 November 2016, https://goo.gl/lV7uAd.

Jokić, V, Dželebdžić, O \& Petovar, K 2015, 'Human capital and its spatial distribution as limiting factors for the balanced development of Serbia', Spatium, no. 34, pp. 46-55.

Kallioras, D 2010, 'Regional Inequalities in the New European Union MemberStates: Is There a 'Population Size' Effect?', European Spatial Research and Policy, vol. 17, no. 2, pp. 107-116.

Kunzmann, K 2006, 'The Europeanization of spatial planning', in N Adams, J Alden \& N Harris (eds), Regional Development and Spatial Planning in an Enlarged European Union, Ashgate Publishing Limited, Aldershot, pp. 43-63.

Lukić, V \& Matijević, D 2006, 'Opštine u Vojvodini sa najvećim udelom izbeglica uticaj na dinamiku i strukturne karakteristike populacije', Matica Srpska Journal of Social Sciences, no. 121, pp. 103-110.

Lukić, V 2013, 'Population Trends in Serbia and the Implications for Settlement System', Forum Geografic, vol. 12, no. 1, pp.67-74.

Lukić, V et al 2013, 'Dynamic Historical Analysis of Longer Term Migratory', Labour Market and Human Capital Processes in Serbia, Country report developed within the project SEEMIG Managing Migration and Its Effects-Transnational Actions Towards Evidence Based Strategies, viewed 9 March 2016, https://goo.gl/6Rem2h. 
Lukić, V 2016, Two Decades of Refugeeism in Serbia, Statistical Office of the Republic of Serbia, Belgrade.

Massey, DS 1990, 'Social Structure, Household Strategies, and the Cumulative Causation of Migration', Population Index, vol. 56, pp. 3-26.

Martin, P 2005, 'The Geography of Inequalities in Europe', Swedish Economic Policy Review, vol. 12, pp. 83-108.

Michálek, A \& Podolák, P 2011, 'Impact of key socio-economic disparities on migration in Slovakia: economic diversification vs. traditional pattern', European spatial research and policy, vol. 18, no. 1, pp. 71-87.

Miljanović, D, Miletić, R \& Đorđević, J, 2010, 'Regional inequality in Serbia as development problem', Acta geographica Slovenica, vol. 50, no. 2, pp. 254-266.

Miletić, R, Lukić, V \& Miljanović, D 2011, 'Deindustrialization and Structural Change in Commuting Flows in Serbia', Forum geografic, vol. 10, no. 2, pp. 244254.

Molnar, D 2013, 'Dinamika i struktura regionalnih dispariteta u Srbiji tokom perioda 2001-2010. godina', Ekonomski vidici, vol. 18, no. 2-3, pp. 175-189.

Nazarczuk, JM 2015, 'Regional distance: The concept and empirical evidence from Poland', Bulletin of Geography, Socio-economic Series, no. 28, pp. 129-141.

Nikitović, V \& Lukić, V 2010, 'Could Refugees Have a Significant Impact on the Future Demographic Change of Serbia?', International Migration, vol. 48, no. 1, pp. 106-128.

OECD 2016, Well-being Topics and Indicators, viewed 19 May 2016 , https://goo.gl/Pu9m3P.

Portnov, B 1999, 'The Effect of Regional Inequalities on Migration: A Comparative Analysis of Israel and Japan', International Migration, vol. 37, no. 3, pp. 587-616.

Predojević-Despić, J \& Penev, G 2014, 'Emigration zones in Serbia: 2011 Census results', Zbornik Matice Srpske za Društvene Nauke, vol. 148, no. 3, pp. 83-397.

Puga, D 1999, 'The rise and fall of regional inequalities', European Economic Review, vol. 43, pp. 303-334.

Redei, M 2010, 'The Research Evidences of Regional Restructuring', Socialiniai tyrimai/Social Research, vol. 3, no. 20, pp. 124-131.

Statistical Office of the Republic of Serbia - SORS 2013, Economic Activity, Census of Population Households and Dwellings in the Republic of Serbia, Statistical Office of the Republic of Serbia, Belgrade.

Spatial Plan of the Republic of Serbia from 2010 - 2021/SPRS 2010, Agency for Spatial Planning of the Republic of Serbia, viewed 25 November 2016, www.rapp. gov.rs/index.php?idstr $=171$.

Tošić, B, Lukić V \& Ćirković, M 2009, 'Settlements of undeveloped areas of Serbia', Journal of the Geographical Institute "Jovan Cvijic “SASA, vol. 59, no. 2, pp. 59-77.

Williams, A, Balaž, V \& Bondarova, B 2001, 'Border region and trans-border mobility: Slovakia in economic transition', Regional studies, vol. 35, no. 9, pp. 831846. 